\title{
The Productive Waqaf Distribution Model in Improving People's Welfare in Bireuen Regency
}

\author{
Mukhlish Muhammad Nur ${ }^{1}$, Fuadi, Nazli Hasan ${ }^{1}$, Munardi $^{1}$ and Ihsan ${ }^{1}$ \\ \{Mukhlish.mnur@unimal.ac.id\} \\ Islamic Economics Department, University of Malikussaleh, Indonesia
}

\begin{abstract}
Waqaf is an instrument of Islamic economic system to realize economic prosperity in the community. Current poverty data shows that there are still many people in Bireuen Regency who are below the poverty line. While the waqaf potential as one of the instruments to realize welfare is very large. This research is to see the influence of waqaf in improving the welfare of society. Research location in Bireuen Regency. This study uses qualitative and quantitative descriptive analysis methods. From the analysis it was found that $74.4 \%$ of endowments with the method of ijarah and mukhabarah can improve the welfare of waqaf recipients in the Regency and the remaining $25.6 \%$ are influenced by other factors.
\end{abstract}

Keywords: Waqaf and welfare

\section{Introduction}

Waqaf with various terms attached to it is one of the important instruments in the history of human civilization. According to (Qahf, 2000). Waqaf instrument has been known by all civilizations of society in this world since time immemorial. Every community has public-owned facilities that are needed by the majority or a handful of people. In the previous community, there were facilities for houses and places of worship. In addition there are also water source facilities, roads and public places, so there are also venues for performances and others in the form of land and buildings intended to provide various service facilities to the general public. All these facilities are not owned by one person, but the facility is left to people to be guarded and maintained by pastors or cinema management.

The description above strengthens the argument that waqf has existed since time immemorial and has an important role in improving the welfare of the community in the form of providing public facilities for the benefit of all people, especially relating to religious affairs. Where the management of the waqaf institution is handed over to the pastors and performance management.

In the Koran (2008) it is stated that the Kaaba is the first house built for the benefit of the general public (3:96). This opinion is in the opinion of the scholars who say that the Ka'bah was built by the Prophet Adam As, while the Prophet Ibrahim and the Prophet Ismail only perfected its development, the Ka'bah was the first religious waqaf in the history of human civilization. Whereas other opinions which say that Prophet Ibrahim built the Ka'bah, the Ka'bah is the first religious waqaf in the history of Islamic civilization, namely the hanif religion of Prophet Ibrahim, or he is the first religious waqaf that aims to legitimize Allah Almighty (Qahf, 2000).

In the study of jurisprudence, the Schoolars of figh have different views about the meaning of waqaf in terms. Abu Hanifah said that waqaf is holding an object which 
according to law remains the property of the waqf (giving the waqf) in using its benefits for virtue. Maliki School says that the waqf does not release the property that is represented by the wakaf (wakif) ownership, but the waqf prevents the wakif from taking actions that can release its ownership of the property to others and the waqf is obliged to give up the benefits and may not withdraw the waqf. Imam Shafi'i and Imam Ahmad bin Hanbal said that the waqf is releasing the property represented from the leadership of the waqf after the perfect procedure of the representative body (Direktorat wakaf, 2006).

Based on the above definition, it can be concluded that waqaf has a worship dimension and socio-economic. On the one hand, endowments aim to get closer to God Almighty and on the other hand aim to establish a harmonious relationship between the rich and people who are economically weak.

While the meaning of waqf according to Qahf is a change in the pattern of treatment of waqaf assets that are only consumptive in the direction of infesting these assets into productive assets. Investment activities on waqaf assets will not only be able to provide benefits but also income to be consumed by future generations, both collectively and individually.

The meaning of waqf as expressed by Qahf raises a new paradigm in treating waqaf assets. Waqaf assets are no longer seen as dead assets that are not empowered otherwise the waqaf assets must be invested in productive sectors. By investing in the productive sector will have an impact on the value of benefits enjoyed by present and future generations. In addition, with the investment will have an impact on the accumulation of waqaf assets from time to time with the additional income from the proceeds of the waqaf asset investment.

According to the official website of the waqf information system (siwak) of the Ministry of Religion of Bireuen (2018) the number of waqf in Bireuen Regency up to 2018 was 6,744 with an area of $4,010.48$ ha. The data shows that the potential of waqf in the Regency is very potential. With this potential, if it is empowered optimally it will have a significant impact on the welfare of the people in Bireuen Regency. meanwhile, the Bireuen population in the poverty line according to the Central Bureau of Statistics of Bireuen Regency (2018), the number of poor people in Bireuen Regency in 2017 was 71,540 people $(15.87 \%)$. These data indicate that the population of Bireuen who are at the poverty line is still relatively large.

The enormous potential of waqf in Bireuen Regency requires the attention of all stakeholders. Based on interviews with the Head of the Islamic Guidance Section of the Ministry of Religion, Bireuen, that so far there has been empowerment of waqf land in Bireuen Regency. He explained, that the waqf land that was represented for the benefit of the mosque was not all buildings built on it, but the land was partly handed over to the peasants with a profit sharing scheme. When harvesting, the results are divided between Nazhir and the cultivator (Yusuf, 2017). According to the Head of the Ministry of Religion of the Bireuen Regency, he explained that the practice of productive waqf had not been so dominant in Bireuen Regency. Among the causes are the lack of socialization about productive waqf and lack of support from the parties to succeed productive waqf (Idris, 2017).

Based on the description of the above problems, this article wants to raise the issue of productive waqf distribution in improving the welfare of the people in Bireuen Regency. 


\section{Methodology}

This study examines the model of productive waqaf distribution that can improve the welfare of waqaf recipients in Bireuen Regency. Population and sample in this study are waqaf recipients who receive waqaf in productive form from the waqaf institution owned by the village in Bireuen Regency. The method of preparation in this study is non-probability sampling (Sarwono, 2006). The data used in this study are primary data and secondary data. Primary data is obtained directly from the recipients of productive waqaf through interview procedures (Raco, 2010). While secondary data was obtained through books, journals, websites of the Ministry of Religion of the Republic of Indonesia. To analyze the data obtained through the distribution of questionnaires to the recipients of productive waqaf, the tools that are used for analysis tools with the help of SPSS and Microsoft Excel software are used for data tabulation. While the data analysis method used is simple regression and descriptive analysis.

\section{Result And Discussion}

\subsection{Waqaf Management}

Based on the search for waqf data inputted into the Ministry of Religion Waqf Information System (Siwak) in Bireuen Regency, each sub-Regency has a different amount and land area. The number and extent of waqaf land can be seen in the following table:

Table 1. Number of Land of Waqf in Bireuen Regency in 2018

\begin{tabular}{llll}
\hline No. & District & Total & Area $(\boldsymbol{H a})$ \\
\hline 1 & Samalanga & 520 & 83.72 \\
\hline 2 & Jeunieb & 142 & 12.46 \\
\hline 3 & Jeumpa & 280 & 28.32 \\
\hline 5 & Peusangan & 982 & 94.39 \\
\hline 6 & Mandapura & 808 & $3,012.86$ \\
\hline 7 & Peudada & 84 & 10.52 \\
\hline 8 & July & 496 & 17.84 \\
\hline 9 & Term & 417 & 52 \\
\hline 10 & Pandarah & 436 & 91.75 \\
\hline 11 & Kota Juang & 70 & 1.87 \\
\hline 12 & Kuala & 122 & 9.34 \\
\hline 13 & Peusangan Selatan & 355 & 154.36 \\
\hline 14 & Peulimbang & 525 & 75.91 \\
\hline 15 & Kuta Blang & 666 & 160 \\
\hline 16 & Simpang Mamplam & 421 & 74.53 \\
\hline 17 & Peusangan Siblah Krueng & 280 & 186.74 \\
\hline & Total number & 6744 & $4,142.04$ \\
\hline
\end{tabular}

Source: www.siwak.kemenag.go.id (accessed 28 August 2018)

Based on the table above it can be concluded that the activities of waqaf in Bireuen Regency spread throughout the sub-Regencys in Bireuen Regency. This also 
shows that the community's interest in endorsing their wealth for the benefit of religion is still relatively high. Although the interest in representation spreads throughout the sub-Regencys in Bireuen Regency, the number and extent of the land represented is very varied. There are five sub-Regencys that have the most and broadest number and area of waqf land, namely the sub-Regency as in the following table:

Table 2. Number of Waqf Land in Bireuen Regency 2018

\begin{tabular}{llll}
\hline No & Sub-Regency & & Rank \\
\hline 1 & Peusangan & 982 & 1 \\
\hline 2 & Gandapura & 808 & 2 \\
\hline 3 & Kuta Blang & 666 & 3 \\
\hline 4 & Peusangan Selatan & 525 & 4 \\
\hline 5 & Samalanga & 520 & 5 \\
\hline 6 & Peudada & 496 & 6 \\
\hline 7 & Term & 436 & 7 \\
\hline 8 & Simpang Mamplam & 421 & 8 \\
\hline 9 & July & 417 & 9 \\
\hline 10 & Kuala & 355 & 10 \\
\hline 11 & Peusangan Siblah Krueng & 280 & 11 \\
\hline 12 & Jeumpa & 260 & 12 \\
\hline 13 & Peulimbang & 160 & 13 \\
\hline 14 & Jeunieb & 142 & 14 \\
\hline 15 & Kota Juang & 122 & 15 \\
\hline 16 & Makmur & 84 & 16 \\
\hline 17 & Pandarah & 70 & 17 \\
\hline & & 6744 &
\end{tabular}

Source: www.siwak.kemenag.go.id (data processed, 2018)

Based on the table above shows that Peusangan sub-Regency occupies the first position in terms of the number of waqf land, then followed in the second position of Gandapura sub-Regency, and the third position in Kuta Blang sub-Regency and in the last position occupied by Pandrah sub-Regency. However, if viewed from the aspect of land area, the position changes. This is as shown in the following table:

Table 3. Total Land Size of Waqf in Bireuen Regency 2018

\begin{tabular}{llll}
\hline No & Kecamatan & Area $(\boldsymbol{H a})$ & Rank \\
\hline 1 & Gandapura & $3,012.86$ & 1 \\
\hline 2 & Peusangan Siblah Krueng & 186.74 & 2 \\
\hline 3 & Kuala & 154.36 & 3 \\
\hline 4 & Peusangan & 94.39 & 4 \\
\hline 5 & Term & 91.75 & 5 \\
\hline 6 & Samalanga & 83.72 & 6 \\
\hline 7 & Peusangan & Selatan 75.91 & 7 \\
\hline 8 & Kuta Blang & 75.43 & 8 \\
\hline 9 & Simpang Mamplam & 74.53 & 9 \\
\hline 10 & July & 52 & 10 \\
\hline 11 & Peulimbang & 28.81 & 11 \\
\hline
\end{tabular}




\begin{tabular}{llll}
\hline 12 & Jeumpa & 28,32 & 12 \\
\hline 13 & Peudada & 17,84 & 13 \\
\hline 14 & Jeunieb & 12,46 & 14 \\
\hline 15 & Makmur & 10,52 Fighting & 15 \\
\hline 16 & city & 9,34 & 16 \\
\hline 17 & Pandrah & 1,87 & 17 \\
\hline & & $4,010.85$ & \\
\hline
\end{tabular}

Source: www.siwak.kemenag.go.id (data processed, 2018)

Based on the table above, when compared with table 2 it can be explained that the area of waqf land in Gandapura sub-Regency is greater than the area of waqf land in Peusangan sub-Regency . Even so, when compared in terms of numbers, waqf land in Peusangan sub-Regency is more compared to waqf land in Gandapura sub-Regency.

Furthermore, it can be explained that the largest area of waqf land is in Gandapuran sub-Regency, followed by Peusangan Siblah Krueng sub-Regency, the third is in Kuala sub-Regency and the last is in Pandrah sub-Regency.

\subsection{Simple Linear Regression}

Data collected through interviews with recipients of waqf are then regressed with the SPSS program. Regression result can be seen in the following table:

Table 4. Results of Simple Linear Regression

\begin{tabular}{|c|c|c|c|c|}
\hline \multirow[t]{2}{*}{ Model } & \multicolumn{2}{|c|}{$\begin{array}{l}\text { Unstandardize } \\
\text { d Coefficients }\end{array}$} & \multirow{2}{*}{$\begin{array}{l}\text { Standardiz } \\
\text { ed } \\
\text { Coefficient } \\
\text { s } \\
\text { Beta }\end{array}$} & $\mathrm{t}$ \\
\hline & B & $\begin{array}{l}\text { Std. } \\
\text { Error }\end{array}$ & & \\
\hline $\begin{array}{l}\text { (Constan } \\
\text { t) }\end{array}$ & $\begin{array}{l}201,9 \\
13.31 \\
4\end{array}$ & $\begin{array}{l}173,9 \\
73.55 \\
9\end{array}$ & & \\
\hline$X$ & 1.525 & & 175,863 & 8.701 \\
\hline
\end{tabular}

According to the table above, it can set up an equation as follows:

$\mathrm{Y}=201,913.314+1.525 \mathrm{X}$

From the formula above, kontansta as much as 201913 states that if the independent variable is considered constant, the average income of earning waqaf recipients in Bireuen Regency is Rp. 201,913,314.

The productive waqaf regression coefficient of 1.525 states that each additional productive waqaf capital of 1 rupiah will increase the income of the productive waqaf recipient in Bireuen Regency by Rp. 1,525.

To see the relationship and the influence between productive waqf and income of productive waqaf recipients can be seen in the following table: 
Table 5. Correlation and Determination Coefficients

\begin{tabular}{ccccc}
\hline Model & $R$ & $R$ Square & Adjusted $R$ Square & Std. Error of the Estimate \\
\hline 1 &, $863^{\mathrm{a}}$ &, 744 &, 735 & 454157,041 \\
\hline \multicolumn{4}{c}{ Source: primary data processed, 2018}
\end{tabular}

Correlation coefficient value is 0.863 or $86.3 \%$, this means that the relationship between productive waqaf variables and productive waqaf recipient income is very strong because the value is between 0.75-0.99.

The coefficient of determination is 0.744 or $74.4 \%$ means that $74.4 \%$ of the income of recipients of productive waqaf is influenced by productive waqaf and the remaining $25.6 \%$ is influenced by other variables outside this study. This indicates that the recipients of productive waqaf in Bireuen Regency in addition to earning their income from the management of waqaf given to them.

\subsection{Discussion}

Based on the regression results above, it shows that productive waqf can improve the welfare of the people in Bireuen Regency. the regression results are reinforced by interviews with a number of Productive waqaf recipients. Based on the results of the interview it was found that there were two models of waqaf in Bireuen Regency, namely the Ijarah and Mukhabarah models. The application of Ijarah in the management of productive waqf objects, nadhir is the first party as the party that rents out, while the tenant is the second party who takes advantage of the goods rented with the obligation to reward the amount of the amount agreed to the first party.

Ijarah in the management of productive waqf objects, can occur for example in waqf objects in the form of land, buildings, vehicles and so on. For example waqf land in the form of agricultural land can be leased as housing, offices, shops and so on; vehicles such as cars can be used as objects for rental or transport business and others.

The second model is productive waqaf with the Mukhabarah scheme. Mukhabarah is a form of cooperation between agricultural landowners and smallholders to cultivate them with profit sharing methods where landowners contribute to giving land to farmers, while smallholders contribute to cultivating waqaf land by bearing all the productivity. Application in the management of waqf in the form of agricultural land, then one of the ways to manage it can be done with al-Mukabarah. Nadhir acts as the owner of agricultural land and the other party is the peasant farmer. The division of results according to the agreement, however, it must be based on the value of justice and consideration that is good in society.

\section{Conclusion}

That in fact waqf is an instrument of the Islamic economic system. In the midst of slowing economic growth, the productive waqf is an alternative for increasing economic growth. From the results of the study, there are two models of productive waqf applications in the District namely the ijarah and mukhabarah models. After going through the analysis, the two models have a positive and significant influence on improving the welfare of the people in Bireuen Regency. 


\section{Acknowledgment}

This research was conducted with the help of grants from the Directorate of Research and Community Service. On this occasion the researchers wanted to thank the Directorate of Research and Community Service and also to the Malikussaleh University Research and Community Service Agency and to the parties involved.

\section{References}

[1] Agama, D. (2008) Al-Quran. Klaten: PT. Macan Jaya Cemerlang.

[2] BPS (2018) Kabupaten Bireuen Dalam Angka 2018. Edited by B. P. S. K. Bireuen. Bireuen: Badan Pusat Statistik Bireuen.

[3] Direktorat wakaf (2006) Fiqih Wakaf. Jakarta.

[4] Idris, Z. (2017) wawancara, tanggal 23 Agustus 2017.

[5] Kementerian Agama (2018) Sistem Informasi Wakaf, siwak.

[6] Qahf, M. (2000) al-waqf al-Islamy: tatawwuruhu, idaratuhu, tanmiyatuhu. Damaskus: Dar al Fikr.

[7] Raco, J. . (2010) 'Metode Kualitatif (Jenis, Karakteristik, dan Keunggulannya)'. Jakarta: Grasindo, pp. 1-18.

[8] Sarwono, J. (2006) 'Metode Penelitian Kuantitatif \& Kualitatif', Edisi Pert(Graha Ilmu).

[9] Yusuf, R. (2017) wawancara, tanggal 23 Agustus 2017. 